\title{
EVALUATION OF THE EU-CANADA COMPREHENSIVE ECONOMIC AND TRADE AGREEMENT (CETA) IN TERMS OF TURKISH FOREIGN TRADE
}

\author{
DOI: 10.17261/Pressacademia.2017.695 \\ JEFA- V4.-ISS.3-2017(7)-p.275-281
}

\author{
Ilhan Gullu ${ }^{1}$, Nazife Ozge Kilic ${ }^{2}$, Omer Sanlioglu ${ }^{3}$ \\ ${ }^{1}$ Nevsehir University, Nevsehir, Turkey, igullu@hotmail.com \\ ${ }^{2}$ Ağrı Ibrahim Çeçen University, Ağrı, Turkey, nokilic@agri.edu.tr \\ ${ }^{3}$ Erciyes University, Kayseri, Turkey. omersanlioglu@gmail.com
}

\section{To cite this document}

Gullu, I., Kilic, N.O., Sanlioglu, O., (2017). Evaluation of the EU-Canada comprehensive economic and trade agreement (CETA) in terms of

Turkish foreign trade. Journal of Economics, Finance and Accounting (JEFA), V.4, Iss.3, p.275-281.

Permemant link to this document: http://doi.org/10.17261/Pressacademia.2017.695

Copyright: Published by PressAcademia and limited licenced re-use rights only.

\begin{abstract}
Purpose-Comprehensive Economic and Trade Agreement, CETA that European Union signed with Canada on November 30,2016 has the quality to result in economic, social and cultural consequences by making norms as compatible not only by removing tariff barriers differently from formers. It has been expected that agreement which removes tariff barriers at the rate of $99 \%$ increases the trade between each two countries at the rate of $23 \%$. In addition to this, consequences that cause some concerns in terms of Turkey that is still candidate country to EU are possible. Turkey had stayed out of negotiation period of CETA as is the case with meetings of Transatlantic Trade and Investment Partnership (TTIP) that EU started negotiations with USA. On the other way, Turkey has been affected by CETA because of applying Customs Union Agreement with EU since 1996. Like agreements that EU has made with other countries, EU-Canada Comprehensive Economic and Trade Agreement is going to deepen the negative effects of Customs Union Agreement on foreign trade of Turkey.

Methodolgy- In this study, Comprehensive Economic and Trade Agreement, CETA, had been discussed in the view of basic indicators subjecting to foreign trade. Possible effects of CETA had been analyzed on Turkey economy because of that Turkey participate in European Customs Union.

Findings-It had been seen that first of effects of Comprehensive Economic and Trade Agreement on Turkey economy had consisted of two sections as particular to CETA and TTIP.

Conclusion-Turkey has been affected by CETA because it was applying Customs Union Agreement with EU since 1996. Like agreements that EU has made with other countries, EU-Canada Comprehensive Economic and Trade Agreement is going to deepen the negative effects of Customs Union Agreement on foreign trade of Turkey.
\end{abstract}

Keywords: European Union, Canada, foreign trade, Customs Union, Turkish economy, CETA.

JEL Codes: F, F1, F13, F15, F19

\section{INTRODUCTION}

On the one hand, the EU is continuing negotiations with the USA within the framework of the Transatlantic Trade and Investment Partnership/TTIP, on the other hand it signed the Comprehensive Economic and Trade Agreement/CETA with Canada on November 30, 2016. Although it remains modest compared to TTIP, it represents a market consisting of nearly 550 million consumers when it is considered as a whole. On the other hand, it will be the EU's neighboring region to the USA, which is the world's largest economy, in the case that TTIP agreement cannot come into force or is delayed. Canada is the country with the best economic indicators in the G7 group since the 2000's in addition to its population of approximately 36 million (2015 data) and GDP valued at 1,671 billion euros (44,500 Euros per capita). It has made free trade agreements with countries and regions like North American Free Trade Agreement/NAFTA (1994), Israel (1997), European Free Trade Association/EFTA (2009), Jordan (2012) and South Korea (2014), has undertaken the responsibilities within the frame of international organizations such as WTO and NATO, and it has made its economy dynamic by revising it. 
CETA has a different place in the EU's commercial integration efforts with North America. To expand the political and cultural influence area although it is basically economic is in question for the EU. Its cultural and historical ties with England and France further shorten Canada's distance to the EU compared to the USA's distance to the EU. Thanks to this feature, Canada, the largest trade partner of which is the USA, allows the EU to fully integrate with the North American market.

While entering the sixtieth year of its foundation, the EU is on the one hand facing the problems caused by the integration process, on the other hand it continues to strengthen its influence area with new economic and cultural ties on a global scale.

However, the negative impacts of CETA on EU economy in case of its implementation, although they are less compared to the example of TTIP, are expressed by some effective groups and organizations in the EU public opinion. The drawbacks put forward by the EU are the issues that should not be ignored by Turkey due to its Customs Union Agreement implemented with the EU. In this study, the EU-Canada Free Trade Agreement will basically be discussed in terms of the EU's integration efforts, and its effects on countries that are not included in the process but included in the EU project like Turkey will partially be examined.

\section{LITERATURE REVIEW}

The relations between the EU and Canada, particularly political, economic and cultural relations, have developed in a multilateral way from past to present. The two countries have been two important actors with common goal in commercial and economic relations, sharing similar obligations in favor of the multilateral trading system. In the field of regional integration, EU-Canada relations are based on trade and economic cooperation agreement in 1976. In the subsequent years, a large number of agreements enriching commercial activities and expanding the sectors were made between the parties. However, Recognition of Mutual Similarities Agreement (Accord sur la reconnaissance mutuelle des évaluations de la conformité) dated 1998 among these agreements was the basis for CETA. ${ }^{1}$

The negotiations that began in 2005 were suspended in 2006 by waiting the conclusion of the Doha Round negotiations conducted by the WTO. Then, the EU and Canada resumed the negotiations in parallel with the negotiations carried out by the WTO in order to strengthen mutual commercial relations. The official calls on CETA were initiated in 2009. The first example of the contract was put forward in 2014, it has been finalized by being rearranged upon both sides' objections. The entry into force of the agreement requires the completion of a three-stage process involving the governments, the European Parliament and national parliaments.

Two problems have been encountered in the governments phase; the first one, Belgian government could not ratify the agreement because of the veto of the two of the six regional parliaments. The second one was the objection of the Romanian and Bulgarian governments justifying that its citizens were not granted the right of free movement by Canada. The objections of the two countries were resolved as a result of mutual negotiations. The German government approved the agreement text but the German Constitutional Court put forward some reservations. The Austrian prime minister also expressed his reservations. In France, some non-governmental organizations using the term "Trojan horse" for TTIP put forward their negative attitudes on the subject. There are also reasons put forward for the content in addition to the reasons against the free trade agreement in principle such as the fact that it would destroy much more than the business opportunity it would establish, it would pose a threat in terms of public services, and it would neglect the environmental, health and social rules in the European standards. Worries of businesses in agriculture sector are the most important of them. There are some concerns regarding the fact that multinational US companies operating in the field of agricultural food and the headquarters of which are in Canada would easily get into the EU market using CETA, and that they would disrupt the EU standards with hormonal tomato meat or chlorinated chickens and products.

The agreement is expected to be approved by the European Parliament in January 2017 in the event that the government phase will be concluded as intended. ${ }^{2}$

It is estimated that the approval process of the agreement text will be extended by the national parliaments over a very long period of time. While the parliaments and senates of some countries are involved in the process as in France, the approval of regional parliaments of some countries is required as in the case of Belgium. The agreement text needs to be approved by a total of 38 parliaments including 28 country's parliaments for the entry into force of it. The process cannot be completed in case of the refusal of one of the said parliaments.

\footnotetext{
${ }^{1}$ The negotiations on trade policies are conducted by the European Commission on behalf of the EU and 28 member states by taking opinions from the member countries and the European Parliament. Along with the entry into force of the CETA, the abrogation of 1998 Recognition of Mutual Similarities Agreement was envisaged.

${ }^{2}$ The approval of the agreement text in the European Parliament is taken for granted. Because a great majority of right (PPE), center (ADLE) and social democrat (S\&D) parties are positively approaching.
} 
However, the EU decided to implement the agreement after translating it into the languages of the member states to take advantage of the benefits it would provide as soon as possible. ${ }^{3}$ The third phase, in other words the approval of national parliaments was not awaited after the completion of the final approval process, in other words after the approval of the European Parliament in the second stage.

\section{CONTENT OF THE COMPREHENSIVE ECONOMIC AND TRADE AGREEMENT (CETA)}

The EU-Canada Trade and Economic Agreement is a new generation agreement in which almost all customs duties have been abolished and the norms have been harmonized. It is deeper and more comprehensive compared to other free trade agreements as it liberalizes the service trade, paves the way for the investments and regulates the intellectual property rights.

The fact that it is an agreement aimed at removing almost all customs duties which are already at low level between both sides is in question. It is estimated that the norm type of barriers to which European exports are exposed will decrease from $36 \%$ to $3 \%$ in this way, and this will provide 600 million euros savings for the European exporters. Thus, the doors of the market valuing 30 billion euros will have been opened for the European entrepreneurs. According to the European Commission, liberalization of public services will provide 6 billion increase every year for the EU's GDP (Abbundo, 2016). 4 The agreement is considered to be a very ambitious initiative because it contains a wide range of comprehensive issues. "This agreement made with Canada, which is one of the world's most advanced economies, will open new horizons for the European and Canadian businesses as it facilitates entry into the goods and services market. It will give Europeans with opportunity to step into the North American market, thus it will be instrumental for the growth of employment in Europe" (Barroso, 2013:1). The following points can be listed among the targets set to increase mutual volume of trade:

- Increasing agricultural exports,

- Reduction of many non-tariff barriers,

- Facilitation of mutual investments,

- Optimal protection of copyrights.

Some issues such as consumer safety in the field of visual services or health and food (hormonal meats or genetically degraded food products/OGM) were excluded from the scope of the agreement upon the mutual consents of the parties.

Table 1: Scope of CETA

\begin{tabular}{|c|c|}
\hline Within the scope & Out of the Scope \\
\hline $\begin{array}{l}\text { Customs duties, agricultural, geographical signs } \\
\text { (indications géographiques) }{ }^{5} \text {, public market, patent, } \\
\text { public services, norms, financial services, environment, } \\
\text { arbitrage courts, corporate cooperation, professional } \\
\text { circulation, }\end{array}$ & $\begin{array}{l}\text { Audio-visual (Audiovisuel), OGM (genetically degraded } \\
\text { organisms) hormones and chlorine, }\end{array}$ \\
\hline
\end{tabular}

Source: http://www.lemonde.fr/les-decodeurs/article/2016/10/18/tout-comprendre-du-ceta-le-petit-cousin-du-traitetransatlantique_5015920_4355770.html (The datas are compiled from this site)

Along with the agreement, about nine thousand customs duties will be abolished in all industrial products, in almost all agricultural and food products except for some sensitive products such as milk, chicken and eggs.

\section{THE EFFECTS OF COMPREHENSIVE ECONOMY AND TRADE AGREEMENT (CETA) ON TURKISH ECONOMY}

Canada is one of the most prosperous countries in the world when its GDP and Income Per Capita of about 45.000 dollars are taken into account. Canada economy in which manufacturing, mining and service sectors come to the forefront is rich in natural resources and is an energy exporter. It is a member of the North American Free Trade Agreement / NAFTA along with the USA and Mexico, and its most important trading partners are the USA, Mexico and China. As it is understood, the Comprehensive Economy and Trade Agreement will put Turkish economy into the influence area of global actors such as the EU and Canada and the US and China.

\footnotetext{
${ }^{3}$ Which chapters would be applied temporarily were not clarified before the approval process of the agreement was finalized.

${ }^{5}$ The system in question is called "L'appellation d'origine protégée (AOP)" in France. Accordingly, all of the production steps of a product are performed according to a method which is known in a defined region and brings quality to the product. AOP is an EU mark and protects the product name in the EU territory.
} 


\subsection{Overview of Turkey-Canada Economic Relations}

Diplomatic relations between Turkey and Canada were established in 1943 and continued on security and military cooperation issues within the frame of NATO during the Cold War years. The two countries cooperated within the United Nations and Organization for Security and Co-operation in Europe/OSCE. Mutual relations continued in economics and finance along with the establishment of the G-20 group in 1999. However, economic dimension of relations began to develop as of the 1990s and continued in the shadow of political problems as of the $2000 \mathrm{~s}$

Turkey has a foreign trade of about 351 billion dollars by 2015, 19 billion dollars of which (7 billion dollars of exports and 12 billion dollars of imports) were realized with North America. In the distribution of Turkish foreign trade according to the North America region, USA is in the first place with about 17 billion dollars. In this case, the USA is the fifth among the countries from which Turkey exports and the fourth among the countries it imports. Canada is behind the first twenty countries with Turkey is trading by its trade volume close to 2 billion dollars. 6 85\% of Turkey's 850 million dollar-export to Canada consists of industrial products, and $15 \%$ of which consist of agricultural products. While $82 \%$ of the imports from Canada consist of industrial products, the share of agricultural products is $8 \%$. Although the foreign trade with Canada constitutes $1 \%$ of Turkish foreign trade, it is important when free trade agreements made or is being made by Canada with the USA, and by the EU with the USA are taken into account.

Agreements have been made between Turkey and Canada on issues such as the prevention of double taxation (1990), cooperation in the field of textile trade (1995), cooperation in the energy field (1998) and social security (2001) (Oruç, 2008:7).

Although Canada and Turkey have been involved in organizations such as NATO, OSCE, OECD and G20 together, it cannot be said that this situation has been sufficiently reflected in economic and commercial relations. In 2003, the bilateral relations created a stressful atmosphere due to Canada's approach to events of 1915, and this situation negatively affected the foreign trade.

\subsection{Its Effects within the Scope of CETA and TTIP}

The two significant initiatives of the EU covering the North American region in the context of the free trade agreement also affect the Turkish economy through the EU. The effects of Transatlantic Trade and Investment Partnership, TTIP and Comprehensive Economic and Trade Agreement, CETA on Turkish foreign trade take place through the Customs Union Agreement that we have been implementing with the EU since 1996.

Turkey, pursuant to Article 10 of the Association Council Decision No. 1/95, committed to make foreign trade regime compatible with the EU and approximate the Common Customs Tariff of the Community to the legislation on collective foreign trade in its relations with the third countries. Turkey, as required by Article 16 of the Association Council decision, has signed agreements with various countries in parallel with the Free Trade Agreements made by the EU with various countries.

Both CETA and TTIP, by their consequences, are not the agreements the influence area of which is limited only to member countries. When Turkey's EU membership process is taken into account, the effects of the EU-Canada and EU-US free trade agreements in terms of Turkish economy can be listed below:

-The fact that the EU will start negotiations with a high-volume economy like the USA brings with it some concerns in Turkey due to the Customs Union between us Especially, the fact that US products can enter Turkey without duty through $\mathrm{EU}$ is the main element of the loss. This situation is expected to further disrupt the existing trade balance against Turkey (Akman, 2013:13).

- Turkey has been out of the negotiation process despite being within the influence area of the CETA and TTIP. The fact that Turkey is not included in the decision mechanism of the EU during the negotiation process is the beginning of the problems faced by Turkey due to such agreements.

This situation causes Turkey to face unfair competition in trade made with the third countries. Although the aforementioned trade agreements do not yet include the customs union, Turkey will be affected due to the common customs tariff applied with the EU. The negativities experienced on foreign trade since 1996 when it applied customs union agreement with the EU will increase. In 2013, Turkey made an attempt to sign a free trade agreement parallel to CETA in order to remove the drawbacks of the Comprehensive Economic and Trade Agreement but could not get a result. Turkey has made similar agreements with 21 countries in line with the free trade agreements signed with the EU. However, there are three countries with which Turkey has not made similar trade agreements despite presence of EU's trade agreement including Algeria, Mexico and South Africa. While these countries have obtained an opportunity to sell duty-free goods to 
Turkey, Turkish exporters cannot take advantage of the same right due to lack of bilateral agreement. Following the EU's free trade agreement with these countries, Turkey's foreign trade deficit has increase by 86 -fold with Mexico and by 2 -fold with the Republic of South Africa (Erem, 2016).

Turkey will continue to face the same problems not only in CETA or TTIP but also in all of the free trade agreements that the EU will make with the third countries later.

- The Customs Union Agreement implemented by Turkey with the EU has restricted the expectations against Turkey. Areas such as agriculture, services and public procurement have been excluded from scope of the customs union, this also has brought an asymmetric structure to the existing relation. Although Turkey has accepted the EU customs tariff in imports, some products are subject to restrictions in the case of export. The current situation is limiting Turkey's export capacity in agriculture and processed agricultural products and also makes its export capacity in industrial products dependent on imports. Thus, businesses in Turkey, in a sense, are encouraged to make an assembly-based production.

\subsection{CETA-Specific Effects}

The Comprehensive Economic and Trade Agreement (CETA) signed between the EU and Canada is a new-generation trade agreement and has a content to ensure unity of norms just beyond reducing customs tariffs. It is an agreement that liberalizes the service trade, facilitates investments, and brings common regulations in areas such as environmental and competition policies, intellectual property rights. With this aspect, it brings regulations that will be reflected in economic, social and cultural areas. Turkey's businesses and consumers will also benefit from the benefits that the agreement will provide to the European economy, businesses or consumers. However, there will be some restrictions for Turkey due to the Customs Union Agreement being applied with the EU. When Turkey's EU membership process is taken into account, the effects of the EU-Canada free trade agreement on Turkish economy can be listed below:

- Canada undertakes to open the public market areas, municipal services and the health sector located both in the federal area and provinces to the European suppliers. Thus, the open part of Canadian public market to the European will rise from $10 \%$ to $30 \%$. On the other hand, European products will be protected without accepting high costs in some parts of Canada. European brands will be protected for an additional two years especially in the pharmaceutical industry. Turkish businesses with competitive capacity in these areas will also be able to take advantage of the opportunities like the EU countries' businesses.

- The researches carried out suggest that the EU'S GDP will increase by 12 billion euros per year due to the overall positive effects of the agreement. The said increase will be seen in the sectors with an increasing export capacity including processed agricultural products, wine, cosmetics, pharmaceuticals, ready-made clothing and textile products. In addition, the simplification of legal transactions applied during the clearance of the goods will prepare the climate for the development of the businesses exporting to Canada, especially SMEs.

- Turkey-Canada foreign trade volume has increased by eight-fold since 1990 until today. "It is possible that the volume of trade will increase to 10 billion dollars if a free trade agreement is signed between the two countries. Canadian companies may play important roles in infrastructure investments in Turkey that foresees to invest 110-120 billion dollars in energy projects over the next ten years (Vardan, 2015)."

- The determination regarding the harmonization of the rules that regulate the intellectual property rights is also stressed by the CETA. Many products of European origin, as well as in France's various cheese brands, have been identified with the region where the production is made and have been allowed to benefit from the protection right in the Canadian market. Since Turkey has not been included in the negotiation process, the same thing is not the case for Turkish products with regional character.

In addition to the related effects of the Customs Union Agreement between Turkey and the EU due to its asymmetrical features, the potential effects mentioned on the EU foreign trade and economy will also be the case for Turkish foreign trade and economy.

\section{CONCLUSION}

It can be thought that the free trade agreement signed between the EU and Canada (CETA) has more limited effects with respect to its potential in terms of parties' interests and its worrying drawbacks compared to the agreement with the USA, the negotiations of which are going on (TTIP). However, it is an important step that can lead to regional and global changes. The structures like CETA or TTIP have important roles in managing the crises on a global scale. Since such agreements will bring member states closer together, the common attitude that needs to be adopted for the problems such as global warming and environmental pollution will be easier. The efforts revealed by Canada's French-speaking Kebek region during the signing process of the CETA indicate that there is a potential that will ensure that the two parties with common values will adopt a common attitude. 
However, the CETA's approval process by the governments has revealed some problems that may arise in the future. First of all, the EU's new trade agreement initiative has not received approval from all members in an environment where the issue of the UK's resignation from the EU is discussed. On the other hand, the reservations for the TTIP agreement implemented with the USA are going on. These also show that the capacity of the EU to become a global actor is limited. The fact that the Constitutional Court that allowed the approval of the agreement put forward some conditions based on some reservations in Germany is an example of it. The court asked the government to regulate the conditions that allowed Germany to withdraw from the agreement if it is requested in the future (Pelouas, 2016). ${ }^{7}$

As it can be remembered, the Free Trade Agreement was signed between the EU and South Korea in 2010, and it was put into practice temporarily in 2011 without waiting for the completion of the process. The agreement in question was approved by the French Parliament in 2013 and by the Italian Parliament in 2015 (Hiault, 2016). ${ }^{8}$ The CETA agreement was also envisaged to be implemented without waiting for the conclusion of the approval process. However, the process is not guaranteed to result in a similar way. The possibility that the agreement will be rejected by at least one of the national assemblies will confront the parties with quite complicated problems. This situation also limits the expansion capacity on a global scale while damaging the democratic identity of the EU. Because "The process followed at the signing stage of the CETA weakened the strength of the actors on the part of the EU. On the one hand, this situation will cause the trade agreements to be negotiated hereinafter to be lighter and less ambitious, on the other hand the representatives of EU institutions will not be considered to be authorized to sign a trade agreement by the opposite side. The restructuring of the CETA agreement in the negotiation process leads to the emergence of this understanding (Şahinalp, 2016)."

The fact that the TTIP negotiations between the EU and the USA have not been finalized results in directing the reservations in the public opinion towards the said agreement to the CETA. While European Commission indicates that both agreements would particularly be for the benefit of SMEs, some active circles in the European public opinion totally oppose against TTIP and CETA and draw attention to negative results. For instance, when positive effects of TTIP on SMEs are taken into account, it is stated that only $0.7 \%$ of the SMEs in France export to the USA, and the remaining $99 \%$ of them will face problems. It is suggested that the known free trade agreements were digressed during TTIP and CETA negotiations, the rules to be applied in the market to be created were not regulated fairly, therefore US-based multinational companies would exploit the environmental, tax-related and social areas. The agreement gives a multinational company that has invested in any country to file a suit against that state in case of determining a public policy contrary to its own interests. According to the Nicolas Hulot foundation, the CETA brings contradictory results with COP 21 signed in Paris in December 2015. Similar associations and foundations are concerned that the use of Canadian petrol, which causes more pollution than petrol, will become widespread in European countries due to the terms of the CETA agreement.

As in the case of TTIP, Turkish economy will be affected by the CETA because of the fact that it is not the participator of the said process but is included in the EU project. This agreement will deepen the existing consequences of the Customs Union Agreement applied between Turkey and the EU, despite not as well as TTIP.

It is possible to generally sort out the benefits to be provided by the CETA in terms of Turkey based on the benefits expected from TTIP: The Free Trade Agreement gives Turkey the opportunity to trade in a wider area compared to the EU market. Due to the implementation of the Community Common Customs Tariff against third countries, Turkish consumers will face a wider range of products, and businesses will have increased their ability to transfer technology. Besides, small and medium enterprises/SMEs expect a tougher competitive environment. Unlike the cost competitiveness faced by Turkish businesses due to the free trade agreement made between China and the EU in previous years, the creation of technology-assisted intense competitive environment will be inevitable as import restricting means such as product standards will also lose their effectiveness along with the free trade agreement between the EU-Canada. On the other hand, many factors including the fact that Turkish consumers are not conscious about the health conditions related to goods and services, the efficiency problems of public institutions and organizations, non-governmental organizations in this area, and the gaps in legislative regulations cause concerns about the possible negative consequences of CETA.

7The opponents in Germany are mentioning the concern that the government will take steps back in later stages as well as the ongoing TTIP negotiations with the US, and that the agreement will cause the regulations available in Germany to be impaired. On the other hand, left party group Die Linke appealed to the Constitutional Court on the grounds that the CETA is contrary to the Constitution.

\footnotetext{
${ }^{8}$ In similar cases in which the EU signs a Free Trade Agreement with a third country, the approval of national parliaments is resorted as a requirement of democracy, and the agreement is implemented temporarily before the approval process is completed. However, the approval process of an agreement in practice may take a long time or may be rejected in the process. According to the European Parliament deputy (PPE) and the Trade Commissioner Franck Proust, it is necessary to make a reform on the approval process of the trade agreements, and majority or absolute majority should be substituted for unanimity.
} 
The issue of how to revert the consequences of the problems that will be caused by the implementation of the CETA without the approval of the national parliaments of the EU countries in the future has not been clarified. Only the German Constitutional Court did not ignore this problem and allowed the government to approve provided that taking the option to leave the CETA.

In addition, in the agreement, multinational companies have been enabled to file a suit against national governments in the case that they claim that the public sector operate contrary to their own interests. EU countries may not be concerned about this situation based on their sound legal systems, but there is a worrying situation when legal gaps in Turkey are taken into account.

In conclusion, apart from the fact that FTA between EU and Canada will deepen the debates in Turkey's EU membership process as of the date of implementation, it will extend the distance between Turkey and EU like in each FTA made by the EU with the third countries. The Customs Union Agreement, which was presented as a step making Turkey closer to the EU by the government of that period in 1995 , is leading to take another step in the opposite direction in this way twenty years after being put into practice.

\section{REFERENCES}

Akman, S. (2013), “AB-ABD Transatlantik Ticaret ve Yatirim Ortakliği (TTIP) ve Türkiye”, Türkiye Ekonomi Politikaları Araştırma Vakfı.

Aichele R., Felbermayr G., “CETA: Welche Effekte hat das: EU-Kanada-Freihandelsabkommen auf Deutschland?” ifoschenelldienst 67, 51/52, December, 2014, 20-30.

AT-Türkiye Ortaklık Konseyi, 1/95 Sayılı Ortaklık Konseyi Kararının 10. Maddesi, http://www.mfa.gov.tr/1-95-sayili-ortaklik-konseyi-kararigumruk-birligi-karari.tr.mfa

Barroso José Manuel, "Commission Europeenne Communique De Pressel'ue et le Canada concluent les négociations pour un accord de libre-échange", Bruxelles, le 18 Octobre 2013.

Conseil De L'union Europeenne, “936/09 Wto 80 Services 21 Cdn 13 Restreint Ue”, en date du, Bruxelles 15 décembre 2015, pp:1-19.

D’abbundo, A., “Pourquoi le traité commercial UE-Canada fait débat”, Le Croix, 14.10.2016, Erişim: 01.11.2016.

Erem Onur, “AB-Kanada Serbest Ticaret Anlaşması Türkiye'yi Nasıl Etkileyecek?” BBC Türkçe, 4 Kasım 2016.

Fritz Thomas, "Analyse und Bewertung des EU-Kanada Freihandelsabkommens CETA", Hans Bockler Stiftung, Berlin, 2015.

Güllü, İ., “AB ve ABD Serbest Ticaret Anlaşması Sürecine Türkiye-AB Gümrük Birliği Anlaşması Özelinde Bir Bakış”, Bilge Strateji, Cilt 6, Sayı 4, Güz 2014, 89-106.

Hiault R., “Quel avenir pour la politique commerciale de l'Europe?”, Les Echos, Erişim:27/10/2016.

Oruç Şaban, 2008, "Kanada Ülke Raporu, İstanbul Ticaret Odası, Ekonomik ve Sosyal Araştırmalar Şubesi

Pelouas Anne, "Le CETA, enjeu principal de la visite de Manuel Valls au Canada", Le Monde, Erişim:13/10/2016

Senat, “Comptes Rendus De La Commission Des Affaires Europeennes”, Mardi 11 Octobre 2016,

Şahinalp A., "Tarihi CETA Anlaşması Konusunda Yanıt Bekleyen Sorular”, Dünya, 1/10/2016.

Türkiye Avrupa Birliği Ortaklık Konseyi, Türkiye, 1/95 Sayılı Ortaklık Konseyi Kararı, 6Mart 1995 Brüksel.

Türkiye'nin Ottawa Büyükelçiliği, Türkiye-Kanada Siyasi İlişkileri,

http://ottava.be.mfa.gov.tr/ShowlnfoNotes.aspx?ID=151986

TC. Dışişleri Bakanlığı, "Türkiye-Kanada Siyasi ve Ekonomik İlişkileri”, http://www.mfa.gov.tr/turkiye-kanada-siyasi-iliskileri.tr.mfa, Erişim: 07.11.2016

"T.C. ile Kanada Arasında Gelir ve Servet Üzerinden Alınan Vergilerde Çifte Vergilendirmeyi Önleme ve Vergi Kaçakçılı̆ına Engel Olma Anlaşması", 14 Temmuz 2009, Ottava. http://www.gib.gov.tr/fileadmin/mevzuatek/uluslararasi mevzuat/kanada.pdf

Vardan, Ö. C., “DEIK/Türkiye-Kanada İş Konseyi ve Kanada-Türkiye İş Konseyi (CTBC) 12. Ortak Yıllık Konferansı”, 4 Mayıs 2015 İstanbul.

Vaudano M., “Tout comprendre au CETA 'le petit cousin’ du traité Transatlantique, Le Monde, 18.10.2016." LErişim: 30.10.2016. 